From Politics to Poetics: Revolution, Nostalgia and Memory in the Exile Poems by Wole Soyinka and Mahmoud Sami Al Barudi

\author{
By \\ Dr. Islam Ahmed Hassan Al-Sadi \\ Lecturer of English Literature, Faculty of Arts \\ Mansoura University
}

Dr. Yousra Mostafa Rashed

Lecturer of English Literature, Faculty of Arts, Mansoura University

DOI: 10.21608/jfpsu.2021.66866.1049

العقد الثذامن عشر / يوليو - 2021هـ 


\title{
From Politics to Poetics: Revolution, Nostalgia and Memory in the Exile Poems by Wole Soyinka and Mahmoud Sami Al Barudi
}

\begin{abstract}
The hypothesis of this paper is to examine poetics of exile, nostalgia and memory in the poetry of Wole Soyinka and Mahmoud Sami Al Barudi. Revolting against western influence, colonialism and economic exploitation are among the issues modern Arab and African poets have dealt with. The analysis is based on the analytical/ comparative view of the selected poems. Postcolonial criticism focuses on the literature of cultures and colonized nations that developed in response to colonization. For Soyinka, post- independence poetry aims at exposing the ugly reality of the ruling regime. For Al Barudi, Arab nations of Africa fought colonization for hundreds of years and resistance poetry is an integral part of Arabic literature in general. It affected Egyptians and rebels in particular politically, socially and culturally. Consequently, hundreds of poets were exiled or imprisoned for resisting colonization. This paper attempts to address the following questions: 1) How was the symbol of "motherland" employed in a Romantic manner in the poetry of Al Barudi and Soyinka to express their nostalgia and memory? 2) How each one of them was successful in expressing the unique philosophy of "revolting" against governments? 3) How the symbol of exile was different for each one of them yet serves as a motif for beautifying and idealizing "the motherland"? The selected poems are relevant since they elaborate the social mission of poets in expressing reality and exposing ugly regimes.
\end{abstract}

Keywords: Poetics of Exile, idealizing homeland, Al Barudi, Soyinka, resistance poetry 


\section{من عالم الساسة إلي الإنشائية الشعرية: ثالوث الثورة، الحنين و الأكري في أشعار"المنفي" لوولي شوينكا و محمود سامي البارودي}

المستخلص

تبحث هذه الورقة شعرية المنفى، الحنين والذكري في أشعار وولي سوينكا ومحمود سامي البارودي.

إن الثوة على النفوذ الغربي والاستعمار والاستغلال الاقتصادي من القضـايا الشائكة التي تتاولها الشعراء العرب والأفارقة المعاصرون. المنهجية في هذه الورقة هي النظرة التحليلية / المقارنة للقصائد المختارة. بالنسبة لشوينكا ، يهدف شعر ما بعد الاستقلا إلى كشف الحقيقة القبيحة للنظام الحاكم. بالنسبة إلى البارودي ، حاربت الدول العربية في إفريقيا الاستعمار لمئات السنين وشعر المقاومـة جزء لا يتجزأ من الأدب العربي بشكل عام. لقد أثرت عليهح سياسيا واجتماعيا وثقافيا. ونتيجة لذلك ، تم نفي أو سجن مئات الثعراء لمقاومتهم الاستعمار • تحاول هذه الورقة معالجة الأسئلة التالية: 1) كيف تم توظيف "الوطن الأم" بطريقة رومانسية في شعر البارودي وشوينكا للتعبير عن حنينهم وذاكرتهم؟ 2) كيف نجح كل واحد منهم في التعبير عن فلسفة "الثورة" الفربدة ضد الحكومات؟ 3) كيف كان رمز المنفى مختلفًا بالنسبة لكل واحد منهم ومـع ذلك يعمل كعنصر لتجميل وإضفاء المثالية على "الوطن الأم"؟ تعتبر القصـائد المختارة ذات صـلة لأنها توضـح الرسـالة الاجتماعيـة للثـعراء في التعبير عن الواقع وكشف الوجـه القبيح للإستعمار والحكومات الظالمة.

الكلمات المفتاحية: أشعار المنفي، تعظيم الوطن، البارودي، شوينكا، شعر المقاومة 


\section{Introduction}

Mahmoud Sami Al Barudi (1839 - 1904) was an outstanding Egyptian political figure and poet and the fifth Prime Minister of Egypt. For so long, he has been considered a key figure in the development of Arabic literature. He relied heavily on several poets as main influences in his poems. The quality that distinguishes him the most was his clinging to turath "heritage" and his plea for modern poets to imitate the classics and to preserve Arabic identity in their writings. He was deeply interested in the poetry of classical writers from several poetic movements and this was apparent in the array of poems throughout his literary career. In addition, Egypt and the concept of "home" shaped a major source of inspiration in his writings as manifested in his Diwan. He was a poet with sincere and affectionate concern for the problems of society and the masses. A thorough reading of his poems shows a score of themes that synthesize his desire of the empowerment of the helpless masses.

Wole Soyinka (1934- ) is a Nigerian poet, playwright and essayist of international acclaim who plays an influential role in Nigeria's history of revolution and politics as an influential figure. He was born in Nigeria and for him; his homeland is the focus and main theme in writing. His parents instilled in him both a religious and a political aspiration that formed his thought. Throughout his life, he asserts the fact that his attempt is to popularize and revolutionize poetry as a social and political path to freedom and identity restoration. James Gibbs illustrates:

Soyinka was brought up, educated and worked until the age of twenty- in what was then called the Western Region of Nigeria and in Lagos. He is a Yoruba and although he has travelled widely, he has returned to Yorubaland to work. His present post at Ifa, a spiritual center of the Yoruba is conveniently symbolic. It is his actual and spiritual home. (3)

Soyinka immediately has become a political and a poetic influence all over the world. Since the beginning of his writing career, he earned an international appraisal as one of Africa's powerful revolting writer. A poet and a writer, he has published eleven plays, a collection of satirical dramatic plays, two volumes of poetry, two novels and an autobiographical. 


\section{Resistance Poetry by Al Barudi and Soyinka:}

During the nineteenth century, Britain has emerged as a great colonial power. New Zealand, Canada, the Middle East, Africa... became under its power and dominance. Although postcolonial criticism did not become a major force in literary studies until the 1990s, several school of colonial studies investigate antiregime poetry as anti-colonialism. Some works were written by the colonized or the former colonized nations as a testimony of the period of colonialism. Accordingly, any analysis of postcolonial literary work might as well fall under the paradigm of post-colonial critical analysis. The works of Al-Barudi show that he considered himself a campaigner for change in regard to poetry, politics and influence. He was a "poet of ideas and ideals, as well as inveterate introspection, would undoubtedly have concurred with the high value Schiller attaches to the contributions made by the Sentimental poets" (Deyoung 6). He managed to speak for his community in plea for freedom and more rights for Egyptians from all classes. His literary knowledge of the classical era and the influence of this period on his poetic language are apparent in his honest expression of feelings, frankness, and diction. His diction pleases both peasants and the sophisticated class and was accessible to all as it represents mass culture and community. The emphasis here is on his patriotic poems:

In fact, Al Barudi patriotic poems not only reflected the rise of the nationalist movement in Egypt, but also contributed to both the articulation and wider circulation of its main ideas and aspirations. Basic terms such as "adl" Justice, "hurriya" freedom and "shura" consultation... were effectively expressed in his poetry and communicated to his readers. (qtd. in Deyoung 9)

The previous lines demonstrate the main ideas in Al Barudi's poetry and the reason behind his relevance in this study to Soyinka. Both poets employ their ideas to illustrate the social role of poets in the development of nationalism.

Soyinka belongs to a family from Yoruba culture, whose backgrounds and beliefs have influenced his works. His area of interest is the severe attack and criticism of Nigerian neocolonial regimes and this have contributed to his living mostly abroad in exile, primarily in the United States of America. His poems are famous in America, Africa, and Asia and are sung all over the world. This is one of the most interesting aspects in postcolonial criticism; how it interacts with 
cultural differences: race, class, religion...etc. This unifies literature in all domains of schools: psychological, ideological, social and so on. Although Soyinka writes English poems, they are all about Nigerian culture, with its masses, minorities, and military system. His writing also includes influences from Western traditions - from classical tragedies to modernist drama. His most notable volumes are Idanre, and Other Poems, Poems from Prison (1969), A Shuttle in the Crypt, the long poem "Ogun Abibiman" and Mandela's Earth and Other Poems. This strong sense of audience and the local touch of his poems helped Soyinka be the first Nigerian to be awarded the Nobel Prize for Literature in 1986.

Al Barudi and Soyinka have opened a new way for writing social poetry. For them, the revolutionary poet is the one focusing on the collective rather than the personal in his writings. Examining their poetry and essays, it is easy to pinpoint a campaign aiming at liberating poetry from the fetters of western influences. Their poetry has an overwhelming nostalgia about the past and a deep sense of anxiety about the present. For them, the successful poet is the one who renders himself as the voice of the marginalized. Thus, they actually revolutionized the mission of poetry. They believed in a nationalistic and social quality of literature, and stated that any poet should express the needs, wishes and interests of the masses specifically the marginalized and the exiled. Soyinka's writings are deeply rooted in traditional African expression like myths, rituals, dance, mime, music and drama.

\subsection{The Romantic Note in Idealizing the "Motherland" as a Sublime Memory:}

Poetry is all about emotion, sincere expressions and personal experiences. Al Barudi has combined good and sincere Romantic traits in his poetry about Egypt. He has been long recognized as a figure of importance in the development of modern Arabic literature. He was an influential Egyptian poet as he re-kindled the spark of the heritage and the love for Egypt that had faded long ago. His "Egypt" is a sublime memory that he spent seventeen years of his life away from. His Egypt is the past with its goodness and progress. He wrote poems about Egypt to bring the past to bear on the present and to celebrate its heritage and influence on other nations. In other words, Egypt represents the memory and nostalgia and it was a major motif in his poems: 
Delighted and joyful, I recalled the memories

Of the past one after another; however, my being

Rejected by my beloved cannot make me immoral.

It was as if I was a drunk who had drunken old

wine held in the store by businessmen for many

Years (metonymy of severe drunkenness)

I have been taken over by love...

(Al Barudi, 1995)

In these lines, Al- Barudi expresses the delight and intoxication that overwhelm the speaker when recalling the memories of the homeland. He delightfully recalls the memories of the past as delicious fragments in his heart. His love is so intense and weary as if he is a drunk excited by old wine. The tone of the lines is sadness mixed with delight over memory. He is taken over by this love and no exile can help him forget the place out of which his aspiration formed and emerged. His lines struck the reader with the playfulness between reality and myth. His vocabulary is colored with nostalgia remembering the days of the past. "Wine" is sometimes a way of escaping but here it is the symbol of intoxication with love. Al Barudi underscores the philosophy of ancient Egyptian heritage of the "Egyptian land" of magic and immortality. Nostalgia over the past is what keeps him alive in the exile. Being "rejected" by his "own love" cannot deny the fact that he was taken over by the drunkenness of this love. No matter the weather or the color of day, his desire to return home almost kills him while still alive. Al Barudi had an authentic romantic sentiment that is apparent in his use of nature and the turning points of sunrise and sun set as an identical background for his anxiety and emotion towards his motherland. With sunset, grief colored him and nothing not even patience and praying can resist this intense grief. People pass by him and wonder what could be the reason. Ultimately they reached the conclusion that he is a helpless prisoner of magic and desire:

When the sun sets, you see me feeling so much

Grief and sorrow that even patience cannot resist it

People say, "Your mood is caused by

Enchantment by magic, which in turn is because you

Are misguided"; however, my mood is caused by a look beyond magic

(Al Barudi, 1995) 
Describing his love and affection over Egypt's misfortune, he wrote sincere poems about Egypt. Nostalgia over his motherland in the exile overwhelms him with grief and sorrow. His "love" is being stolen away and its foundations are being shaken so violently and even the birds are frightened. But he is away in exile and cannot protect this love. This leaves him in a state of helplessness and fear. Even the masses around this "ancient tree" cannot protect it. The cultivator has neglected her and the merchant has given her up. Such dread is all over the place and no time or change is near. The masses are now under a colonial regime that no one dares to sleep or rest in the dead of the night. Heritage is the remaining linkage between the masses and Egypt and the tone again is that of a torn soul between love and torment:

The cultivator, as a result of tyranny, has neglected his hand;

And the merchant, from fear of poverty, has withdrawn his money.

Such dread has become so dominant that none

Can sleep in the dead of night, but remain, vigilant

Woe to such a land! Were it not for the great heritage buried

Therein we would not have lived in its vicinity.

(Khouri 22)

Pride in Egypt and Egyptians is also a recurring theme in Al Barudi's poems on the motherland. As a neoclassicist, he expresses the same tribal pride that is a common feature of classical Arabic poetry. He is thoroughly describing his people as a group of lions covered with blood from the recent battle. When taking the decision to attack, these lions turn amazingly into firelights while in fighting they are quick and overwhelming like thunder storms. When they decide to unite their hands they are like a destructive flood that fears not death or destiny. These lions are well- aware of the prize ahead even after years of fighting and exile. The prize is freedom and better life condition for all people:

There are many young men of my tribe who are

Like grove lions, and when the battlefield is covered

With blood, they have not shelter but their lances.

When they are making decision, they are like the

Firelight; when they are fighting, they are like

Thunder; when they love, they are like the rain;

(Al Barudi, 1995) 
An identical theme in the poetry of Al Barudi and Soyinka is the romantic interest in the "homeland" as a necessity to recover from death and destruction. After all, the term "resistance" is not exclusive to extreme rage but rather to call more attention to the beauty of the colonized land. In postcolonial literature, exile is the symbol of the human loss. Al Barudi and Soyinka claim that the correct way to return to life is to return to the "root" and to return to the goodness of the "motherland": Africa. They believe that the survival of African people before the onslaught of colonization and forces of modernity resides in the roots of Africa. Nigeria, like Egypt as an African country and a developing third world country cannot survive its own share of political, economic, social, religious and tribal traumas.

Like Al Barudi, Soyinka takes great pride in his African roots and most of his poems are filled with controversies on the racial burden among the ideologies of the modern world. He is always busy expressing racial problems and he feels indebted to his Yoruba culture and material. His poetry on Africa is filled with vocabulary from the forests regarding "roots, earth, soil, African magic and lore":

Soyinka speaks of racial burdens but keeps them open to foreign influences and contrasts, he speaks proudly of his debts to Yoruba sources and matrices while celebrating other African and non- African traditions, and with revolutionary impatience he savages some critics. (Jeyifo xix)

In "Dedication: for Moremi", there is a nurturing tone for his daughter, as well as one of protectiveness over the earth and its resources. Soynika incorporates the symbol of the "earth" representing Africa as a symbol of fertility and goodness. Also, he indicates the fact that natural elements of Africa are the symbols of power and strength along with unity and endurance. The earth can be seen as a symbol of the daughter and the daughter can be seen as a symbol of the future. Soyinka gives advice to his daughter through sincere nature similes and metaphors about the earth and the way in which it functions. He employs a creative parallel between the yam plant with its roots and earthy heritage and him as a sacred plant on the land of Africa deeply rooted within. This yam is wholly and completely earthed as roots of baobab. The air 
recognizes her as the daughter of the ancient warrior of Africa. He asks her to hold on to her heritage even in the wildest storms.

The roots of Africa's desert shall always protect her and help her be an ageless brown deposit soil:

As this yam, wholly earthed, yet a living tuber

To the warmth of waters, earthed as springs

As roots of baobab, as the hearth

The air will not deny you. Like a top

Spin you on the navel of the storm, for the hoe

That roots the forests plows a path for squirrels.

Be ageless as dark peat, but only that rain's

Fingers, not the feet of men, may wash you over.

(SurryLibs 2015)

This is Soyinka's example of telling his daughter to be sharp and dangerous like a Nigerian scorpion, but also to be nurturing, gentle, and kind, like a pigeon. $\mathrm{He}$ is clearly displaying the paternal qualities that he imparts on his daughter in a similar fashion in which he is telling the masses of Nigeria to be protective of their new Nigeria. He wraps up the poem with the thought that in the same way we rely so heavily upon the earth, the future generation too must let the earth rely upon us. We must give back to the earth in the way it gives to us.

\section{2 "Revolution" as an Identity Token for the Brave:}

Al Barudi and Soyinka use eloquent and sometimes sophisticated language and style to enhance passionate moral and political commitment than pleasure. In addition, they deploy his creativity and intellect to attack greed, corruption and brutality of the neocolonial African elites. They share a common hatred to hypocrisy and cruelty along with a violent contempt to unjust rulers. Their poems on "revolt" portray authority with all its selflessness, folly, egotism and destruction. The main events that influenced $\mathrm{Al}$ Barudi and triggered his poetic creativity were mainly political and social such as the revolution that occurred during the reign of Isma'il Pasha (1881-1922):

... the notion of linkage between poetry and the political was seen as problematic... Furthermore, the implicit assumption made by modernists- that an author cannot be influential both as a literary figure 
and a political activist- has had a lingering effect on the assessment of crucial $19^{\text {th }}$ century Arab authors like Al Barudi.

(DeYoung 23-24)

Ibn Khadiv, who was acquainted with the lavish careless life of Europe during the rule of his grandfather, Muhammad Pasha (1769-1849), was interested in the life of the palaces, parties, ceremonies and lavish lifestyle. Al Barudi was close to the castle and a keen observant of the vast gap between the life of the court and the life of the masses. The governors' incompetence and the intervention of the colonizers increased the impoverishment of the working classes and the lower classes. In the following lines, he shouts in grief against all corruption and against unjust rulers. Military groups are now moving in order to revolt against the bad conditions of the country and the violations of agreements in Egypt:

How can anyone be free and cultured while

Approving of that which every sinner commits?

Through others have been treacherously hypocritical in their

Religion, praise be to God that I am not of their number.

They decided to rule the people by force, and so they hastened

To violate their established agreements

When oppression continued, a military group raised their

Banners in revolt.

(Khouri, 28)

Thus, most of Al Barudi poems are based on the theme of revolution attacking unjust conditions in which all the masses found themselves with more intervention from the west. The 'Urabi Revolution was an uprising in Egypt from 1879 to nearly 1882. It was headed by and named after the great Ahmed 'Urabi. It aimed at removing the Khedive Tewfik Pasha and ending all sorts of western influence over the country "British or French". The uprising was ended by a fierce war with officers exiled and killed defending Egypt:

Some people say that I revolted to dethrone (the Khedive). Such

Is a defect (disloyalty) far from my character.

Nay, I called for justice, seeking to please God, and

I wanted the people of truth.

(Khouri 27) 
The theme of "revolt and politics" is related to the previously discussed theme of idealizing the "motherland". Al Barudi and Soyinka portray the debunking of hypocrisy and humbug, the relentlessness exposure of the manipulative abuse and misuse of power, knowledge and insight of governors:

Soyinka's use of satire and parody has been particularly effective in his plays, poems, and short dramatic sketches on this theme; consequently, throughout Africa, powerful political figures and forces have sometimes sought, happily so far in vain, to intimidate, silence, or assassinate him. (Jeyifo, xv)

An identical theme in the poetry of Al Barudi and Soyinka is the notion of "revolt" as a path to rebirth. Revolt is a process of cleansing and purification that can only succeed through revolting against unjust rulers. In "I think it rains", Soyinka explains:

I saw it rise

The sudden cloud, from ashes.

Settling

They joined in a ring of

Grey; within,

The circling spirit.

$\mathrm{O}$ it must rain

These closures on the mind, blinding

In strange despairs, teaching

Purity of sadness.

(Website, All Poetry 2010)

In these lines, Soyinka again relies on the nature of Africa using rain, wind, clouds as symbolic images with color imagery from African forests. He employs parallels and associations with the events in Nigeria and the rage within the head and heart of the rebel. He predicts a revolution that shall rise suddenly from the ashes with all the fierce soldiers gathering in a ring of fire. This revolution is a must and is so near that it could almost be smelled in the rain. Sadness, despair and cruelty overwhelm Nigeria and all the masses must rise to protest against cruel baptisms. Rain is used in this poem as a bringer of relief and as an agent of good. It is also a sign of purity and cleansing after long decades of corruption and filth. Rain purifies and cleans. Through the symbolic image of the rain, the 
poet narrates the burdensome thoughts that are stifling him and causing him so much despair and sadness. Soyinka's dissatisfaction with the complicity of the neo-postcolonial dispensation with colonialist practices of power began in the late 1950s while he was a student in Britain. Soyinka illustrates:

It was a single moment at one of the earliest stage of our semiindependence when the first ministers arrived in England. I remember that a group of us went to meet them wanting to discuss issues. Within five minutes, I knew that we were in serious trouble. It was clear that they were concerned with the mechanisms for stepping into the shoes of the departing colonial masters, enjoying the same privileges. (Thomas 144-145)

The idea of "rebirth through revolt" is a universal theme which is to be found in many of both poets' revolt, philosophical and political poems. Therapy requires that a conflicted, traumatized subject must return to the homeland and got incorporated with the roots for strength and power for a successful rebirth. The need to revolt was related to political problems because of several causes:

These diverse causes have been brought together by Soyinka's concern for justice. He parodied the Federal War cry with (To keep Nigeria one, justice must be done). His desire was an egalitarian society as expressed in his words (the need to redistribute Nigeria's wealth equally). He also fought fiercely for human liberty and human rights. (Gibbs, 10)

Protagonists in the poetry of Al Barudi and Soyinka argue that it is pointless and almost meaningless to attempt to build or hope for a life in the future, when you might have to leave the following day or exiled. In the same symphony, a feeling of immortal despair hovers over exile poems by each of them as the speakers "the poets themselves" keep thinking about future and the present generations. The gloomy atmosphere of these poems is intensified by the excessive use of words such as "woe, land, lost love" to stress the fact that the future of the exiled people after revolution has been destroyed forever. They saw and felt the ugly changes brought by "revolutions" and their influence on the lives of the future generation. This is exactly the case with the miserable speakers in the exile 
poems by each poet keep counting and recounting the different types of despair fear in a repetition of the feeling of trauma.

\subsection{Physical vs. Spiritual Exile Cruel Punishment for Liberty Seeking:}

In postcolonial literature, memory is often interwoven with the conflict between the new place and the old home. These feelings of trauma are intense and scar the human psychologically as the rebel is being rejected by the same land he used to fight for. While in exile, Al Barudi recollected his experiences with the 'Urabi Movement and embodied them in a series of moving poems that reflect his self-image as an exiled fighter. His exile poems reveal certain aspects in the general state of confusion which prevail among the exiled after the collapse of their movement, namely suspicion, accusation, despair, guilt, selfdefense, revolt and other mixed feelings born of crushing defeat. He was put to trial and exiled to Sarandib Island in 1882 due to his revolting marches. The recalling of daily suffering makes trauma equally linked to the present as it is with the past, with endless haunting daily suffering of being away from the only true love; the love of home he once defended. The dominance of recalling of memories of home and the psychic suffering is reinforced by the choice of diction in verbs such as "once rooted, earth less, plucked," reflecting the psyche of the exiled against the practices of the unjust regime. In the following lines, he is meditating over the distress that came over him as a price for loving his motherland so much. He is complaining that defending religion or a country can be punished by exile for seventeen years:

I committed no offense which should condemn me to this, my

State. Why (must I suffer) this distress and grief?

Was that, my defense of religion and country, a crime for which

I should be unjustly condemned and exiled?

(khouri 26)

This exile period was a flourish in the writing career by Al Barudi. In the following lines, he addresses Egypt wishing more power and fertility for his beloved motherland. For him, Egypt is the sanctuary for Egyptians, the moving force forward and the only source of safety. In exile, he recalled past memories, playground, family members and the offspring of his childhood to the flowering of youth. The tone is sad and desperate yet mixed with a nostalgic feeling for Egypt; the remaining source of pride after exile: 
Oh Egypt may your shadow be extended (power increased) And your soil be drenched with the pure water of the Nile.

You are the sanctuary of my people and the branching place of My family, the playground of my age- mates and the race course

Of my horses

A country in which youth took off the amulet of my childhood And hung the scabbard of my sword on my shoulder I left behind in its noble kinsmen and neighbors whose image Comes back to me every morning

(Khouri 21)

Al Barudi expresses home sickness, pain of parting with loved ones, and his intense emotional atmosphere, and he wrote more impressive and emotionally nostalgic poems. He expresses the harshness of post-traumatic time in exile that can be portrayed as a mix of love and guilt in the same time. The violent events of the revolution and the loss of friends, families and the loss of Egypt itself cannot be fully grasped as they occurred. In the poems of exile by Al Barudi these memories are treated as segments of flashbacks, nightmares, or other repetitive trauma dreams.

In the same symphony, the exile poems by Soyinka criticize the homeland politics that used the strategies of classification of rebels, people of colors and revolutionary writers. In the exile poems by each of them, speakers were so overwhelmed with the craze for his homeland. On the other hand, Soyinka illustrates: "I, on the other hand, when I was kicked out, used euphemisms to describe my condition, saying 'I'm on political sabbatical!!" I couldn't wait to get back. I was never totally comfortable outside Nigeria," he said, (Reuters 2010). An array of Soyinka's poems encourages everyone who had simply been named as inferior or "African warrior" to overcome their fears and feelings of insecurity and to be proud of their descent and the richness of their heritage. Like $\mathrm{Al}$ Barudi, he refuses to take the identity of the victim and headed a campaign of defiance and challenge to all the paralyzing remnants of fighters against Western intervention. Soyinka was arrested in 1967 for his plea for freedom from unjust regimes and discriminatory governments in an article appealing for a ceasefire during Nigeria's civil war. As a result, he was prisoned for nearly two years in a small cell as a political prisoner for defending Nigeria and for conspiring for a better life for the masses. Several years later, he was released but continued to 
campaign for democracy, freedom, rights to vote and fighting corruption. Soyinka again went into exile in 1994, and was sentenced to death, in absentia, three years later, only returning to Nigeria in 1998.

Soyinka's exile poems are credited with defending Native Nigerian heritage against the false stereotypes of western colonizers through producing a large number of poetry. After all, postcolonial criticism focuses on analyzing the metaphysical, ethical and political concerns about cultural identity, psychological problems of the colonized and his/ her way out. To stress his firm belief in the power of poetry to effect change in the time of rebellion and revolution he conducted several interviews on the time he spent in exile and how he overcame this trauma. Like Al Barudi, he believed those in power often determine what kind of memories to be preserved and in what order, and which memories and histories can be ignored or neglected. In this way, Nigerians could have a history of stories and exile narratives to tell themselves and the future generations. Thus, Soyinka's exile poems gain attention for the histories of the marginalized people in them. His "exile" poems set him as an international figure of Africa:

The simplest versions of the African past offered by a variety of cultural and political Negritude, important as they are as vehicles of resistance during the struggle for independence, need to be examined into a more searching problematic, one that confronts rather than evades the contradictions inherent in the historical development of African society. (Msiska 9)

The psychological and spiritual exile Soyinka felt in his own rightful land left him hopeless and hungry for items of nature from Africa. The only path for this wholeness is to return to the motherland and its natural environment:

This is indeed basis of Soyinka's abiding interest in nature- it is a powerful anchor for the quest for wholeness. Soyinka's obsession with this theme probably makes him one of the last great Romantics, for like the $19^{\text {th }}$ century European Romantics and American Transcendentalists, Soyinka has written powerfully against the tendency of modern Arabic industrial civilization to cut us off from our links with nature. (Jeyifo xv) 
Moreover, Soyinka argues that "exile" is a state of mind. It is related to those who surrender to authority and refuse to take part in any revolt or revolution. However, he further stated that exile can be the name of "the new place" or "the wasteland" that Nigerians might choose in order to escape corruption and havoc instead of attempting to change:

Is there a moment when you know intuitively and accept that you have now truly arrived in exile? If the nature of departure from homeland has been marked by total rejection, by the necessity for a near-total obliteration of memory (The Guardian 2002)

For him, Africa is part of his creation and no ruler shall have the authority to expel him or assassinate him. His exile poems and his poems on Africa focus on one concept: "wholeness". He only becomes whole within the reach of Africa and within the elements of African nature:

Your hand is heavy, Night, upon my brow.

I bear no heart mercuric like the clouds,

To dare

Exacerbation from your subtle plough

Woman as a clam, on the sea's crescent

I saw your jealous eye quench the sea's

Fluorescence, dance on the pulse incessant

Of the waves. And I stood, drained

Submitting like the sands, blood and brine

Coursing to the roots.

Hide me now, when night children haunt the earth (Allpoetry 2010)

He addresses "night" in a meditation upon his memories and his love "the motherland". He implores Fluorescence to dance on the symphony of the waves. All these natural elements are vibrant in his heart as a living proof of his love for Nigeria. There he stands, drained and submitting like the brown sands with blood and brine coursing to the roots. Night feelings of exile and fear are beautifully interwoven with the blackness of Nigeria's earth. Soyink's exile was the common exile all Nigerians felt and went through. Even in exile poems, Al 
Barudi and Soyinka share a romantic tendency that made their poems influential to generations of several culture and nationalities.

\section{Conclusion}

Among the most important characteristics of the poetry of El Barudi and Soyinka is that they believe in the social and political role of the poem as both a responsibility and a mission. Al Barudi was exiled away from Egypt and his best poems are in love of Egypt. Soyinka's exile was different from that of Al Barudi. The psychological and spiritual exile Soyinka felt in his own rightful land left him hopeless and hungry for items of nature of Africa. The only path for this wholeness is to return to the motherland and its natural environment.

An identical theme in the poetry of Al Barudi and Soyinka is the romantic interest in the "homeland" as a necessity to recover from death and destruction. They believe that the correct way to return to life is to return to sources and to return to the goodness of the "motherland"; Africa. Al Barudi and Soyinka have opened a new way in writing. For them, the revolutionary poet is the one focusing on the collective rather than the personal in his writings. Examining their poetry and essays, it is easy to pinpoint a campaign aiming at liberating poetry from the fetters of western influences. Their poetry has an overwhelming nostalgia about the past and a deep sense of anxiety about the present. Their poetry is still read and felt till today in every colonized nation and is well received by next generations. For them, the successful poet is the one who renders himself as the voice of the marginalized.

In this way, both poets actually revolutionized the social mission of poetry. They believe in a nationalistic and social quality of the poem, and stated that any poet should express the needs, wishes and interests of the masses specifically the marginalized and the exiled. The portrait of Al Barudi as a noble rebel who suffered to advance the cause of freedom in his country still resonates strongly among Egyptians. Al Barudi represents a convenient but essential starting point for inquiry into not only how modern Arabic poetry became modern but also how modern Arab politics became, first, a locus for examining questions of identity and how the individual should relate to the collective. Soyinka is one of very few Nigerian writers who truly portrayed the dilemma and trauma of Nigerians after fighting western colonization. He went deeper into the psyche of the warrior and fighter with his memories towards land that 
rejected him into exile. In the same symphony with the poetics of politics, Soyinka has been a factor in Nigerian politics for several years. His attention has been always focused on Africa. Africa is symbolized in Soyink's poems as the woman, the solace, the safe shore.

\section{Works Cited}

Al Barudi, Mahmoud. Samy. Diwan; Ed. Abd al-Rahim1st ed., Beirut, Dar alJayl, 1995.

Allpoetry, https://allpoetry.com/poem/10379361-Night-by-Wole-Soyinka last accessed 2/2/2021.

Deyoung, Terri. Mahmoud Sami All Barudi: Reconfiguring. Syracuse University Press, 2015.

Gibbs, James. Critical Perspectives on Wole Soyinka. Lynne Rienner Publishers, 1980.

Heikal, A. "Evolution of modern literature in Egypt"; Egypt: Dar al-Ma'arif, 1986.

Jeyifo, Biodun. Ed. Conversations with Wole Soyinka. University Press of Mississippi, 2001.

Khafaji, A. "Dirasat fi al-adab al-Arabi al-Hadith wa mudarisah"; Beirut: Dar al-Jayl, 1st ed. (1992)

Khouri, A. Mounah. Poetry and the Making of Modern Egypt. Leiden E. J. Brill, 1971.

Msiska, Mpalive. Postcolonial Identity in Wole Soyinka. Rodopi, 2007

Reuters, https://www.reuters.com/article/idINIndia-45717420100127. Last accessed on 2/2/2021.

Sami el-Baroudi, M. Diwan; ed. Al-Ma'ruf,M.Sh. \& al-Jarimi, A.; Egypt: Dar alMa'arif. (1971)

SurryLibs: $\quad$ https://npdsurrey.wordpress.com/2015/07/13/dedication-frommoremi-by-wole-soyinka/ last accessed 2/2/2021.

---, https://npdsurrey.wordpress.com/2015/07/13/dedication-from-moremi-bywole-soyinka/ last accessed 2/2/2021.

The Guardian, https://www.theguardian.com/books/2002/jul/13/poetry. wolesoyinka last accessed 2/2/2021.

Thomas. Bandele, Biyi. "Wole Soyinka Interviewed" in Wole Soyinka: An Appraisal, ed. Adewale Maja- Pearce. London, 1994 